\title{
ELECTROPHORETIC PATTERN OF HEREDITARY HAEMOGLOBIN DISORDERS IN A REFERRAL CENTRE: A ONE YEAR STUDY
}

\author{
Karim $\mathrm{MM}^{1}$, Yousuf AKMA ${ }^{2}$, Akhter $\mathrm{S}^{3}$, Ahmad M$^{4}$, Sultana $\mathrm{S}^{5}, \mathrm{Al}^{-A z a d} \mathrm{MAS}^{6}$, Karim $\mathrm{MI}^{7}$
}

\begin{abstract}
Introduction: The inherited disorders of haemoglobin are the commonest single-gene disorders with an estimated carrier rate of $7 \%$ among the world population. They occur at particularly high frequencies in population of the tropical and subtropical belt.
\end{abstract}

Objective: To find out the electrophoretic pattern of haemoglobin disorders and to evaluate and compare the diseases in study population.

Methods: A total number of 1370 subjects of both sexes with age range from 6 months to 73 years were included in the study. The study was conducted in Haematology Department of Armed Forces Institute of Pathology, Dhaka. It was carried out from January to December 2012. Patients were selected on the basis of morphological blood film examination and electrophoresis on cellulose acetate at $\mathrm{P}^{\mathrm{H}}$ 8.6.

Results: Among the 1370 subjects, Beta thalassaemia trait was observed in 532(38.83\%) cases, $\mathrm{HbE}$ trait in 313(22.85\%), HbE-Beta thalassaemia in 282(20.58\%), $\mathrm{HbE}$ disease in $146(10.66 \%)$ and Beta thalassaemia major in $97(7.08 \%)$ cases.

Conclusion: The study reveals that, hereditary haemoglobin disorders are common in Bangladesh and are inherited as autosomal recessive Mendelian pattern affecting both male and female.
Key-words: Hemoglobin disorders, Electrophoretic pattern, Beta thalassaemia, Mendelian pattern.

\section{Introduction}

The inherited disorders of haemoglobin are the commonest single-gene disorders, with an estimated carrier rate of $7 \%$ among the world population. They occur at particularly high frequencies in population of the tropical and subtropical belt ${ }^{1}$ and include haemoglobinopathies, characterized by structurally abnormal haemoglobin variants and thalassaemia by partial or total suppression of normal peptide chains of haemoglobin molecules ${ }^{2}$.

More than hundreds of structural hemoglobin variants have been identified in the last three decades. Majority of these results from single amino acid substitution in one or other of the globin chains. The simple system of presumptive identification of these variants by simple electrophoresis still remains an extremely useful procedure though it does not discriminate between different mutants ${ }^{3,4,5}$. The inheritance of haemoglobin disorders follows a simple mendelian pattern. The heterozygous state for a disorder is called "trait" while the homozygous or genetic compound is called "disease". Thalassaemia is the most common inherited genetic disorder and varies in different population group in the world.

1. Lt Col Md Mostafil Karim, MBBS, MCPS, DCP, FCPS (Haematology), Asst Prof, Dept of Transfusion Medicine, AFMC, Dhaka Cant; 2. Col AKM Abu Yousuf, MBBS, FCPS (Haematology), HOD of Haematology, AFIP, Dhaka Cantt; 3. Dr Shahina Akhter, MBBS, FCPS (Gynae \& Obs), MS (Gynae \& Obs), Junior Consultant, Dhaka Dental College; 4. Lt Col Mushtaq Ahmad, MBBS, MCPS, DFM, Assoc Prof \& HOD of Forensic Medicine, AFMC, Dhaka Cant; 5. Lt Col Sharmeen Sultana, MBBS, MPhil, Assoc Prof \& HOD of Phisiology, AFMC, Dhaka Cantt; 6. Lt Col Md Abdus Samad Al-Azad, MBBS, MCPS, DFM, Dept of Forensic Medicine, AFMC, Dhaka Cant; 7. Lt Col Md Iqbal Karim, MBBS, MCPS, DCP, FCPS (Histopathology), Dept of Pathology, AFMC, Dhaka Cant. 
Haemoglobin disorders will become a major issue in developing countries like Bangladesh in this millennium. It is observed that when the world population finally stabilizes, at least $8 \%$ of the population will be carrier or trait ${ }^{6}$. The world population of carrier of Beta thalassaemia trait is reported to be more than 100 million worldwide and about 1,00,000 children with thalassaemia major are born each year. In Bangladesh, no screening program has yet been taken in any population group.

A conservative world health report estimates that $3 \%$ of the population are carriers of Beta thalassaemia and $4 \%$ are carriers of $\mathrm{HbE}$ in Bangladesh $^{7}$. Most of the thalassaemic patients need frequent blood transfusion about every 2-3 weeks interval. As a result good percentage of blood is utilized by them, which is a major burden to the department of transfusion medicine involving a lot of complication and transfusion hazards. So there is a chance of transmission of infectious agents like HCV, HBV, HIV, Plasmodium and Treponema pallidum etc.

\section{Methods}

This study was conducted in the Haematology Department of Armed Forces Institute of Pathology from January 2012 to December 2012 and total number of 1370 cases of hereditary haemoglobin disorders were studied over a period of one year. Armed Forces Institute of Pathology, Dhaka is a referral centre for Armed Forces personnels. Patients were selected on the basis of morphological evidence of haemolytic anemia in peripheral blood film and haemoglobin electrophoresis on cellulose acetate membrane at $\mathrm{P}^{\mathrm{H}}$ 8.6. Age, sex, presenting complaints and family history were noted.

\section{Results}

Among the 1370 subjects, Beta thalassaemia trait was observed in 532(38.83\%), $\mathrm{HbE}$ trait in $313(22.85 \%)$, HbE-Beta thalassaemia in 282(20.58\%), HbE disease in 146(10.66\%) and Beta thalassaemia major was found in $97(7.08 \%)$ cases (Table-IV).
Out of 1370 subjects, $398(29.05 \%)$ were of less than 5 years of age, $142(10.37 \%)$ between 5 to 10 years, $216(15.77 \%)$ between 11 to 20 years, 292 (21.31\%) between $21-30$ years and $322(23.50 \%)$ were of above 30 years of age (Table-l).

Table-I: Distribution of population by age.

\begin{tabular}{|c|c|c|}
\hline Age (Years) & No of Patient & Percentage \% \\
\hline$<5$ & 398 & $29.05 \%$ \\
\hline $5-10$ & 142 & $10.37 \%$ \\
\hline $11-20$ & 216 & $15.77 \%$ \\
\hline $21-30$ & 292 & $21.31 \%$ \\
\hline$>30$ & 322 & $23.50 \%$ \\
\hline Total & $\mathbf{( n = 1 3 7 0 )}$ & $\mathbf{( 1 0 0 \% )}$ \\
\hline
\end{tabular}

Distribution of population by age $(29 \%$ of study population below 5 years and $10 \%$ of study population between 5 to 10 years of age) is shown in Fig-1.
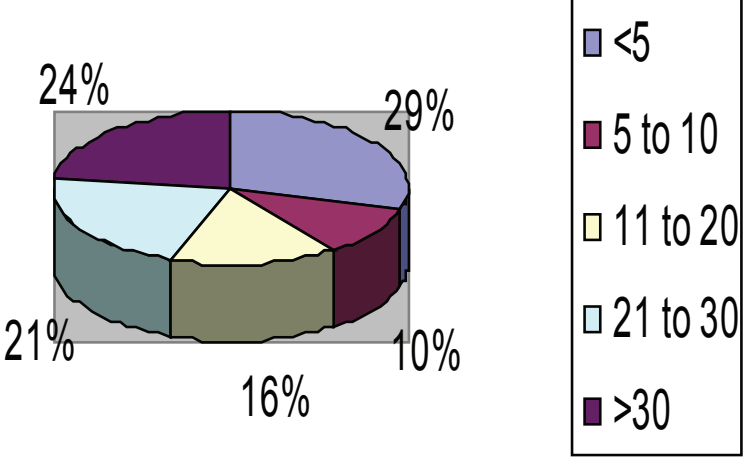

Fig-1: Distribution of population by age.

Among the 1370 subjects, $738(53.87 \%)$ were female and $632(46.13 \%)$ were male.

Table-II: Sex distribution $(n=1370)$.

\begin{tabular}{|c|c|c|}
\hline Sex & No of Patient & Percentage \\
\hline Female & 738 & $53.87 \%$ \\
\hline Male & 632 & $46.13 \%$ \\
\hline Total & $(\mathbf{n = 1 3 7 0 )}$ & $\mathbf{( 1 0 0 )}$ \\
\hline
\end{tabular}

Sex distribution (54\% study population are female and $46 \%$ are male) has been shown in Fig-2. 


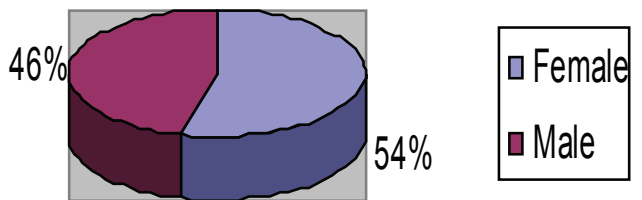

Fig-2: Sex distribution ( around 54\% study population were female and $46 \%$ male).

986 (71.97\%), 712 (51.97\%), 806 (58.83\%), 540 $(39.42 \%)$ and $504(36.79 \%)$ cases presented with weakness, jaundice, splenomegaly, hepatomegaly and fever respectively. 323 (23.58\%) study population were asymptomatic (Table-III).

Table-III: Presenting clinical manifestations.

\begin{tabular}{|l|c|c|}
\hline Symptoms & No of Patient & Percentage \\
\hline Weakness & 986 & $71.97 \%$ \\
\hline Jaundice & 712 & $51.97 \%$ \\
\hline Hepatomegaly & 540 & $39.42 \%$ \\
\hline Splenomegaly & 806 & $58.83 \%$ \\
\hline Fever & 504 & $36.79 \%$ \\
\hline Retardation of growth & 149 & $10.88 \%$ \\
\hline Pallor & 53 & $03.87 \%$ \\
\hline Leg ulcer & 13 & $0.95 \%$ \\
\hline Bony change & 26 & $01.88 \%$ \\
\hline Asymptomatic & 323 & $23.58 \%$ \\
\hline
\end{tabular}

Common clinical presentation among the study subjects were weakness (24\%); jaundice (17\%), splenomegaly (20\%), hepatomegaly (13\%) and fever $(12 \%)$ respectively which are shown in Fig-3.
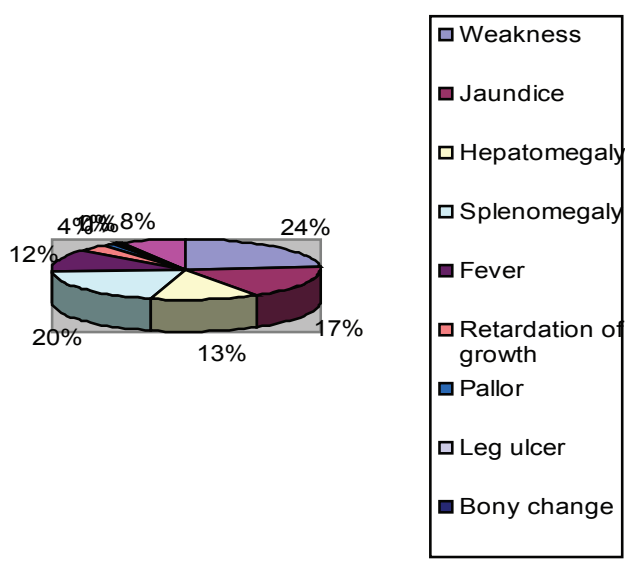

Fig-3: Presenting clinical manifestations.
Among the 1370 subjects, Beta thalassaemia trait was observed in 532 (38.83\%), HbE-trait in 313 $(22.85 \%)$, HbE-Beta thalassaemia in 282 (20.58\%), HbE disease in $146(10.66 \%)$ and Beta thalassaemia major was found in $97(7.08 \%)$ cases (Table-IV \& Fig-4).

Table-IV: Pattern of hereditary haemoglobin disorders.

\begin{tabular}{|l|c|c|}
\hline Disorder & No of Patient & Percentage \% \\
\hline Beta-thalassaemia trait & 532 & $38.83 \%$ \\
\hline Hb-E-Trait & 313 & $22.85 \%$ \\
\hline Hb-E-beta thalassaemia & 282 & $20.58 \%$ \\
\hline Hb-E-disease & 146 & $10.66 \%$ \\
\hline Beta-thalassaemia major & 97 & $7.08 \%$ \\
\hline Total & $\mathbf{( n = 1 3 7 0 )}$ & $\mathbf{( 1 0 0 )}$ \\
\hline
\end{tabular}

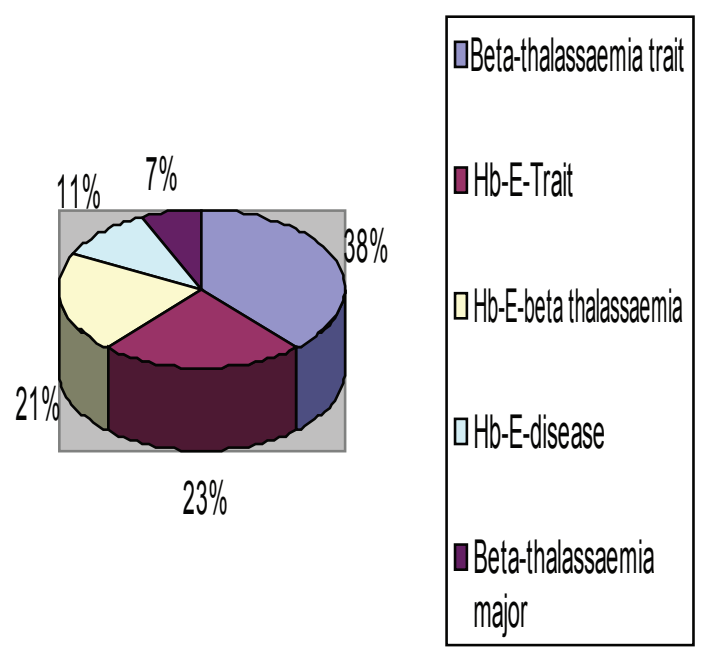

Fig-4: Pattern of hereditary haemoglobin disorders.

\section{Discussion}

In this study, heterozygous Beta thalassaemia trait was found as the most common disorder. Heterozygous $\mathrm{HbE}$ and double heterozygous $\mathrm{HbE}$-Beta thalassaemia were next common disorders. Almost similar findings were observed in others studies ${ }^{8}$. In a study, done in the Deparment of Haematology in Bangabandhu Sheikh Mujib Medical University (BSMMU), Dhaka, Beta thalassaemia trait was found in 99(47.14\%) cases, $\mathrm{HbE}$-Beta thalassaemia in 65(30.47\%), 
$\mathrm{HbE}$ trait $28(13.3 \%), \mathrm{HbE}$ disease in $12(5.71 \%)$ and Beta-thalassaemia major was found in $7(3.33 \%)^{8}$ cases. But in our study $\mathrm{HbE}$ trait was found to be as more common i.e. in $313(22.85 \%)$ cases, and $\mathrm{HbE}-$ Beta-thalassaemia as less common i.e. in $282(20.58 \%)$ cases which are unlike of the study findings carried out at BSMMU. In a study carried out at Myanmar, $\mathrm{HbE}$ trait was found in about $10-20 \%$ cases and in Assam ${ }^{9} 23.9$ $\%$ cases. In our study prevalence of $\mathrm{HbE}$ trait was closely similar to that of the neighboring countries. In another study, prevelance of Beta thalassaemia trait was found to be $18 \%$ in Mediterranean area ${ }^{10}$ which was higher $(38.83 \%)$ in our study. This finding may be due to smaller size of study group.

In another study carried out in Sub-Saharan Africa, the prevalence of Beta-thalassaemia major was found to be $22 \%$ and $\mathrm{HbE}$-Beta thalassaemia ${ }^{11}$ $19 \%$. Prevelance of $\mathrm{HbE}$-Beta thalassaemia in our study population was $20.58 \%$ which was almost similar to above study. But prevelance of Beta-thalassaemia major in our study was $7.08 \%$ which was very less than that of the above study. It may be due to the fact that Beta-thalassaemia major was more common in Sub-Saharan Africa than Southeast Asia.

Prevalence of $\mathrm{HbE}$ in Southeast Asian countries like Myanmar, Cambodia, Laos, Vietnam and Thailand was $30-40 \%$. In China, Philippine, Turkey, Nepal, Sri lanka and Pakistan it was $50-70 \%{ }^{12}$. In our study prevalence of $\mathrm{HbE}$ is $54.09 \%$ which is closely similar to above study. Hereditary haemoglobin disorders are manifested at all ages from minimum 06 months to 73 years. In our study it was found that prevalence of hereditary haemoglobin disoders was higher (39.42\%) in the first decade \& this finding is similar to a study carried out in the Haematology Department of Bangabandhu Sheikh Mujib Medical University, Dhaka ${ }^{8}$. Homozygous Beta thalassaemia was found in more than $20 \%$ of study population in South West Pacific Archipelago of Vanuatu ${ }^{13}$.
But in our study homozygous beta thalassaemia was found in $7.08 \%$ cases which is less than that of the above study. In Tribal population in Tripura and North East India, $\mathrm{HbE}$ carrier comprised $57.65 \%$ of the population and $20.40 \%$ were $\mathrm{HbE}$ homozygotes ${ }^{14}$ which is higher than that of our study. In our study, prevelance of $\mathrm{HbE}$ trait was $22.85 \%$ and $\mathrm{HbE}$ homozygotes comprise $10.66 \%$ of the population.

\section{Conclusion}

In the study it is revealed that hereditary haemoglobin disorders are common in Bangladesh and these disorders are inherited as autosomal recessive Mendelian pattern affecting both male and female. So we just cannot ignore the prevalance of these diseases. In this study, we got heterozygous (trait) like both heterozygous beta thalassaemia trait and heterozygous $\mathrm{HbE}$ trait in significant number. This population is usually asymptomatic, do not require treatment and lead a reasonably good quality life but risk is there as because of the possibility of homozygous or double heterozygous inheritance through marriage of unaware couples or silent spread as trait. This will cause a serious health threat to our nation, if it is allowed to continue without taking measures for prevention.

Finally, in spite of all limitations of the study we have tried to find out whether the hereditary haemoglobin disorders are very common in Bangladesh, so that the health authorities can focus on this matter. Awareness has to be created at national level to reduce the incidence of hereditary haemoglobin disorders in the community. It is mandatory to detect the trait in general population with large scale study and proper premarital genetic counseling should be done. It is time to think about the molecular and prenatal diagnosis to start with in order to prevent further spread of these diseases like hereditary $\mathrm{Hb}$ disorders. 


\section{References}

1. Hoffbrand AV. Postgraduate Hematology. Hemoglobin and inherited disorders of globin synthesis. 6th ed. London: Wiley-Blackwell, 2011: p. 83-4.

2. Ball S. Congenital disorders of hemoglobin and blood cells. Medicine. 2004; 32(5): 20-7.

3. Kattak MF, Saleem M. Structural hemoglobin variants in adult healthy population of Northern Pakistan. Pakistan J Pathol. 1992; 3(2):85-7.

4. ICSH: Recommendation for selected method of hemoglobin $\mathrm{A}_{2}, \mathrm{~A} \& \mathrm{HbA}_{2}$ reference preparation. $\mathrm{Br}$ J Haematol. 1978; 38: 573-8.

5. Fishlidar AJ, Hoffman GC. A practical approach to detection of hemoglobinopathies; Part-III. Lab Med. 1987; 18: 513.

6. Khan WA. Thalassaemia in Bangladesh. Dhaka Shishu Hosp J. 1999; 15: 42-4.

7. Dacies SJ. The haemolytic anaemia. Vol-2. 3rd ed. New York. Churchill livingstone; 1988. p.285-99.
8. Uddin MK, Aziz MA, Hossain MZ, Bhuya MF, Uddin MM, Kobir M. Electrophoretic pattern of hereditary hemoglobin disorders in Bangladesh. $\mathrm{J}$ Dhaka Med Coll. 2010; 19(1): 39-42.

9. Mohanty D, Colah RB, Gorakshakar AC. Prevalence of Beta-thalassaemia and other hemoglobinopathies in six cities in India, a multicentre study. J Community Genet. 2013; 4: 33-42.

10. Lahiry P, Attar SAA, Hegele RA. Understanding Beta-thalassaemia with focus on the Indian subcontinent and the Middle East. J hematology. 2008; 2: 5-13.

11. David J, Weather A. The inherited diseases of hemoglobin are an emerging global health burden. $J$ American Society of hematology. 2010; 5: 82-5.

12. http://en.wikipedia.org/wiki/Haemoglobin E (June 2013).

13. Bowden DK, Hill AV, Clegg JB. High frequency of beta thalassaemia in island population in Melanesia. J Med Genet. 1987; 24(6): 357-61.

14. Das SK, sengupta B, Das N, Talukder G. High incidence of $\mathrm{HbE}$ in tribal populations of Tripura, north East India. Anthropologist Special Issue. 2002; 1: 105-8. 